\title{
CHEMOSPHERE
}

\section{AFLP analysis as biomarker of exposure to organic and inorganic genotoxic substances in plants}

\author{
M. Labra ${ }^{\text {a,* }}$, T. Di Fabio b, F. Grassi ${ }^{\text {c }}$, S.M.G. Regondi ${ }^{b}$, \\ M. Bracale ${ }^{\text {d }, C . ~ V a n n i n i ~}{ }^{\text {d }}$, E. Agradi ${ }^{b}$ \\ a Dipartimento di Scienze dell' Ambiente e del Territorio, Università degli Studi di Milano-Bicocca, \\ P.zza della Scienza 1, 20126 Milano, Italy \\ b Dipartimento di Scienza Farmacologiche, via Balzeretti 9, 20133 Milano, Italy \\ c Department of Biology, Università di Milano, via Celoria 26, 20133 Milano, Italy \\ d DBSF, Università dell Insubria, via J.H. Dunant 3, 21100 Varese, Italy
}

Received 14 May 2002; received in revised form 3 April 2003; accepted 8 April 2003

\begin{abstract}
In recent years several plant species have been in use as bioindicators and several tests have been developed to evaluate the toxicity of environmental pollutants in vegetal organisms. In the present paper Arabidopsis thaliana (L.) Heynh. (ecotype Wassilewskija) was used as bioindicators of two genotoxic substances: potassium dichromate and dihydrophenanthrene. Inhibition of seed germination was observed with both pollutants. AFLP analysis (i) indicated that both substances are genotoxic, (ii) showed that dihydrophenanthrene induces DNA changes in different target sequences than potassium dichromate, (iii) quantified the genotoxic effect using cluster analysis by comparing DNA from treated plants with that of control plants. On the basis of these considerations we suggest that AFLP method is a powerful tool for measuring qualitative and quantitative genotoxic activity due to environmental pollutants. AFLP method can be applied to a wide range of bioindicator organisms and may become a universal methodology to identify target genes for specific genotoxic agents. This could open up possibilities for designing specifically targeted assays and new approaches to risk assessment.
\end{abstract}

(c) 2003 Elsevier Science Ltd. All rights reserved.

Abbreviations: PCR, Polymerase chain reaction; RAPD, Random amplified polymorphic DNA; RFLP, Restriction fragment length polymorphism; AFLP, Amplified fragment length polymorphism

Keywords: AFLP; Arabidopsis thaliana (L.) Heynh.; DNA fingerprinting; Environmental pollutants; Genotoxic effect

\section{Introduction}

In recent years, attention has been given to investigating the occurrence of genotoxic agents in the environment. The increasing concern of the general public and of governments for the welfare of humans and natural environments requires the assessment of new

\footnotetext{
${ }^{*}$ Corresponding author. Tel.: +39-02-64482934; fax: +39-0264482992.

E-mail address: massimo.labra@unimib.it (M. Labra).
}

sensitive and efficient methods for early detection of environmental genotoxic risk. The difficulties arising from direct chemical measurements of pollutants in the field and the interpretation of such measurements in terms of bioavailability, have stimulated strong interest in bioindicators and biomarkers (Lowry, 1995). Bioindicators of contamination make it possible to detect subtle forms of pollution that are hard to measure in the field. Plants are good bioindicators because (i) they play a significant role in food chain transfer and in defining habitat, (ii) they are easy to grow and adaptable to environmental stress, (iii) they can be used for assaying a 
range of environmental conditions in different habitats. In addition, it has been shown that for some chemical agents, comparable results in terms of genetic abnormalities are obtained in plant or animal systems (Minissi et al., 1997) and that plants are more sensitive to some stressors (i.e. herbicides) than animals (Wang and Freemark, 1995). Furthermore, plant-based assays applied to toxicity screening in the environmental field would reduce animal sacrifice and testing costs. The use of plants as bioindicators of genetic toxicity of environmental pollutants has been reported in several studies (Grant, 1994; Knasmuller et al., 1998). Mutagenic activity of chemicals has been analysed with different plant systems such as Allium cepa (Fiskesjo, 1997), Vicia faba (Koppen and Verschaeve, 1996), Trifolium repens (Citterio et al., 2002), and Tradescantia virginiana (Fomin et al., 1999). Chromosome aberration assays, mutation assays, cytogenetic tests and specific locus mutation assays were performed (Constantin and Nilan, 1982; Tardiff et al., 1994; Marcon et al., 1999) with these systems. The advantage of measuring the effect of genotoxic chemical directly on DNA is mainly related to the sensitivity and the short response time. Recently, enormous advances and developments in molecular biology have provided new ways of detecting DNA damage (Conte et al., 1998; Savva, 2000; Citterio et al., 2002). Following the original description of the PCR (Mullis and Faloona, 1987), modifications were described enabling the generation of DNA fingerprints which have been used to screen for biodiversity (Karp et al., 1998).

In this paper we evaluated the application of AFLPs as molecular marker to detect DNA damage in Arabidopsis thaliana (L.) Heynh. caused by environmental pollutants. Results showed that AFLP technique is a powerful tool for screening DNA damage induced by non-lethal levels of organic and inorganic contaminants.

\section{Materials and methods}

\subsection{Plant material and seed germination text}

Arabidopsis thaliana (L.) Heinh (ecotype Wassilewskija) was used as plant material in this study. Experiments were conducted on seed for germination tests and on plants for AFLP analysis.

Dry mature Arabidopsis seeds where soaked in water at $4{ }^{\circ} \mathrm{C}$ for three days before being seeded on Petri dishes containing a filter paper of $90 \mathrm{~mm}$ diameter and in the presence of distilled water or increasing concentrations of potassium dichromate $(2,4,6 \mathrm{mg} / \mathrm{l})$ and dihydrophenanthrene $(25,50,100 \mathrm{mg} / \mathrm{l})$. The seeds were incubated in a growth chamber at a temperature of $25^{\circ} \mathrm{C}$. As a control, 100 seeds were incubated under the same conditions without pollutants. After 6 days in the dark, the germinated seeds were counted. Tests were performed in triplicate.

\subsection{DNA extraction and AFLP analysis}

Arabidopsis thaliana (L.) Heynh. seeds were treated with potassium dichromate $(6 \mathrm{mg} / \mathrm{l})$ or dihydrophenanthrene $(100 \mathrm{mg} / \mathrm{l})$ and were incubated as described in the germination test. After 6 days incubation, a pool of 200 shoots were collected, ground under liquid nitrogen and the DNA was extracted using DNeasy Plant Mini Kit (QIAGEN). Purified DNA concentration of each sample was estimated both fluorometrically and by comparison of ethidium bromide-stained band intensities with $\lambda$ DNA standard.

AFLP was performed as described in Vos (Vos et al. (1995)), except that genomic DNA (200 ng) was digested $(3 \mathrm{~h})$ with the restriction enzymes EcoRI ( $1 \mathrm{U})$ and $M s e \mathrm{I}$ (1 U). DNA fragments were ligated (with T4 DNA-ligase) to EcoRI adapter ( 5 pmol) and MseI adapter (50 pmol) in a final volume of $50 \mathrm{ml}$. Ligation reaction was performed at $37^{\circ} \mathrm{C}$ for $6 \mathrm{~h}$. This mixture was used as template in the pre-amplification reaction containing DNA primers (E01 and M01 of Table 2) complementary to the core of the EcoRI and MseI adapter, respectively. The $50 \mu \mathrm{l}$ amplification mixture contained $20 \mu \mathrm{l}$ of digested/ligated DNA, $50 \mathrm{ng}$ of the selected primers, 200 $\mu \mathrm{l}$ of each dNTP, $0.5 \mathrm{U}$ Dynazyme II (Celbio, Italy) and $5 \mu \mathrm{l}$ Dynazyme buffer. After $2 \mathrm{~min}$ at $94{ }^{\circ} \mathrm{C}$, amplification was carried out for 20 cycles of denaturation ( $45 \mathrm{~s}$ at $\left.94^{\circ} \mathrm{C}\right)$, annealing $\left(30 \mathrm{~s}\right.$ at $\left.60^{\circ} \mathrm{C}\right)$ and extension $(1 \mathrm{~min}$ at $\left.72^{\circ} \mathrm{C}\right)$. After a final extension step $\left(7 \mathrm{~min}\right.$ at $\left.72^{\circ} \mathrm{C}\right)$ the pre-amplifictaion product was diluted at 1:50 with water and used for selective amplification. This was carried out using one of the selective primers (E32, E33, E34 or E37 of Table 1) complementary to the EcoRI adapter and one of the primers (M 36, M38 or M40 of Table 1) complementary to the MseI adapter. The EcoRI-primer was end-labelled with $\gamma^{33}$ P-ATP (Amersham, Italy). The amplification mixture $(20 \mu$, final volume) contained 5 $\mu \mathrm{l}$ of the pre-amplification mixture, $5 \mathrm{ng}$ of labelled EcoRI primer, $30 \mathrm{ng}$ of MseI primer, $200 \mathrm{ng}$ of each

Table 1

Sequences of primers usied for AFLP analysis

\begin{tabular}{|c|c|}
\hline Name & DNA sequence \\
\hline E01 & 5'-GACTGCGTACCAATTC-3' \\
\hline M01 & 5'-GATGAGTCCTGAGTAAA-3' \\
\hline E32 & 5'-GACTGCGTACCAATTCTG-3' \\
\hline E33 & 5'-GACTGCGTACCAATTCAG-3' \\
\hline E34 & 5'-GACTGCGTACCAATTCAA-3' \\
\hline E37 & 5'-GACTGCGTACCAATTCCC-3' \\
\hline M36 & 5'-GATGAGTCCTGAGTAAACC-3' \\
\hline M38 & 5'-GATGAGTCCTGAGTAAACT-3' \\
\hline M40 & 5'-GATGAGTCCTGAGTAAAGC-3' \\
\hline
\end{tabular}


dNTP, 0.5 U Dynazyme II (Celbio, Italy) and $2 \mu 1$ Dynazyme buffer. After 2 min at $94{ }^{\circ} \mathrm{C}$, amplification took place for 36 cycles under the following conditions: denaturation for $30 \mathrm{~s}$ at $94{ }^{\circ} \mathrm{C}$; annealing for $30 \mathrm{~s}$ at $65^{\circ} \mathrm{C}$ for first cycle, followed by lowering of the temperature $\left(0.7^{\circ} \mathrm{C}\right)$ in the next 12 cycles, then at $56^{\circ} \mathrm{C}$ for the remaining 23 cycles; extension for $60 \mathrm{~s}$ at $72^{\circ} \mathrm{C}$. A total of $1.5 \mu \mathrm{l}$ of the PCR-amplified mixture was added to an equal volume of loading buffer ( $80 \%$ formamide, $1 \mathrm{mg}$ / $\mathrm{ml}$ xylene cyanol FF, $1 \mathrm{mg} / \mathrm{ml}$ bromophenol blue, $10 \mathrm{M}$ EDTA, $\mathrm{pH}$ 8.0), denatured for $5 \mathrm{~min}$ at $92{ }^{\circ} \mathrm{C}$, loaded onto a $5 \%$ denaturing polyacrylamide gel and electrophoresed in TBE electrophoresis buffer for $3 \mathrm{~h}$ at 80 Watt. The gel was finally fixed in $10 \%$ acetic acid and exposed to an X-ray film for $24 \mathrm{~h}$. Polymorphic bands were scored by visual inspection of the resulting autoradiograms. For statistical analysis, each AFLP band detected after electrophoresis of the DNA amplification products was scored as a binary character for its absence $(-)$ or presence $(+)$. Two genotypes were being considered similar $(++=a ;--=d)$ or different $( \pm$ or $\mp=b$ and $c$, respectively). The algorithm used to define genetic differences (GD):

$\mathrm{GD}=1-\mathrm{SM}$,

where SM is simple matching coefficient (Sokal and Michener, 1958) computed as,

$\mathrm{SM}=a+d / a+b+c+d$.

The matrices of similarity were then analysed using UPGMA cluster method to obtain dendrogram (Flury, 1988). Data were analysed with the NTSYS-pc version 2.1 computer software.

In addition for each substances, a percentage of polymorphism $\left(P_{(\%)}\right)$ was computed as:

$P_{(\%)}=$ (number polymorphic bands/total detected bands) $\times 100$.

\section{Results}

\subsection{Seed germination test}

The inhibition of seed germination in response to environmental pollutants was evaluated by treating seeds with different concentrations of dihydrophenanthrene and potassium dichromate solutions. Results were expressed as number of seeds germinated (Fig. 1). Data obtained suggested that both substances caused seed germination inhibition. In particular, the organic substance (dihydrophenanthrene) inhibited $85 \%$ of seeds starting from the second treatment concentration (50 $\mathrm{mg} / \mathrm{l}$ ) while the potassium dichromate (inorganic substance) caused $75 \%$ inhibition of seed germination at the maximum concentration $(6 \mathrm{mg} / \mathrm{l})$.
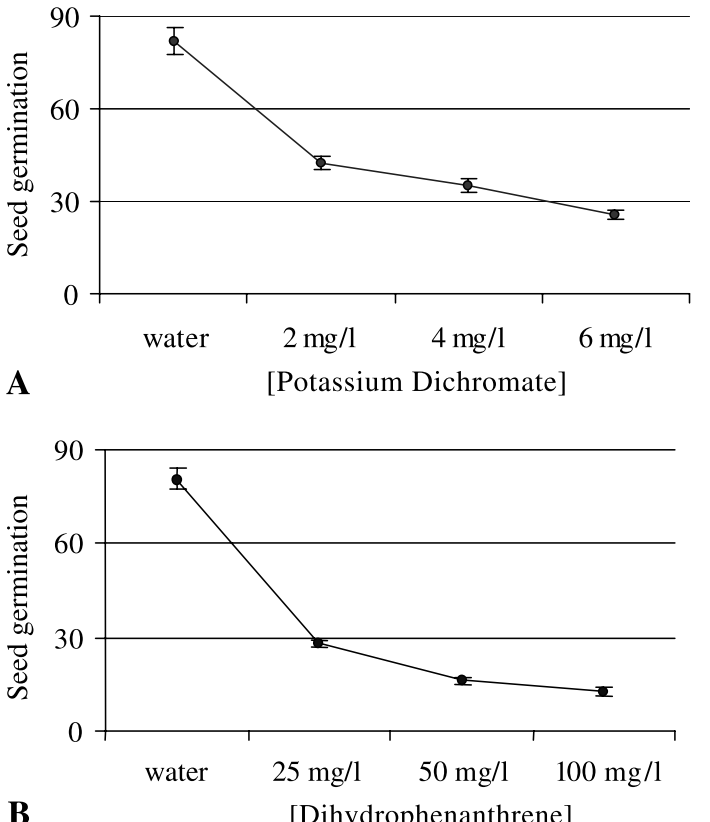

Fig. 1. Seed germination test conducted on Arabidopsis thaliana (L.) Heynh. seed by different concentrations of potassium dichromate (A) and dihydrophenanthrene (B), respectively. The experiments were conduced in triplicate.

These data indicated that both substances considered are toxic agents for plants as described in literature (De Flora et al., 1990; Susa et al., 1997; Dellagreca et al., 2000).

\subsection{AFLP analysis}

With the aim of verifying the genotoxic effect of these substances and quantifying DNA damage, AFLP analysis was performed on DNA extracted from plants treated with both pollutants at maximum concentrations. Four different primer pairs were used for AFLP analysis. A representative example of the results obtained by AFLP analysis is shown in Fig. 2 whilst Table 2 summarizes data obtained for each primers pair. A total of 231 bands were observed, 29 of these were polymorphic for potassium dichromate-treated plants, and 22 for dihydrophenantrene-treated plants. Value of polymorphisms was $P_{(\%)}=12.5 \%$ for potassium dichromatetreated plants and $P_{(\%)}=9.5 \%$ for dihydrophenanthrene treated-plants.

In addition, results showed that both environmental pollutants induced DNA changes (mutation) but in different target sequences (Fig. 2).

Dendrogram of Fig. 3 is a possible graphical representation of AFLP data obtained. A dendrogram consists of many $\mathrm{U}$-shaped lines connecting objects in a hierarchical tree; the height of each $U$ represents the 


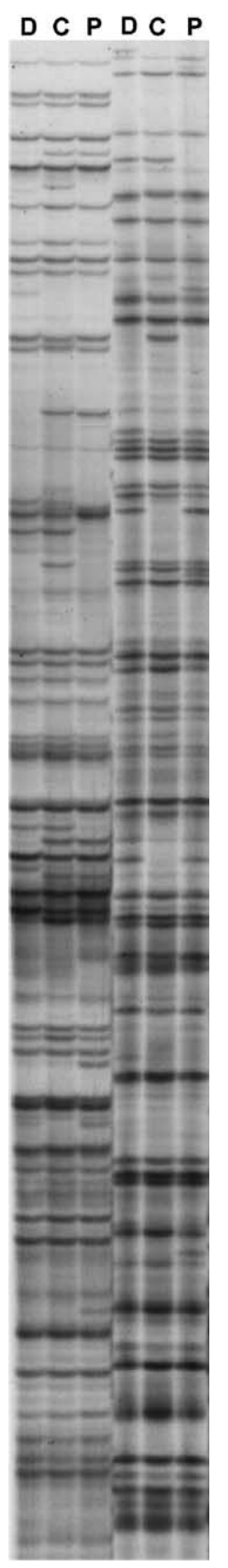

Fig. 2. Examples of AFLP pattern obtained comparing DNA from control (C) and treated (D) dihydrophenanthrene or (P) potassium dichromate plants, using two primer combinations: E34-M36 and E33-M38.

distance between the two objects being connected and the differences between each other. In our analysis the dendrogram showed the relationship between treated samples in comparison with control plant. This statistical analysis allows the DNA damage induced by two different substances to be quantified. We can conclude
Table 2

Number of amplified bands and polymorphic bands detected with each primer combination used in AFLP analysis

\begin{tabular}{lcl}
\hline Primers pair & Total bands & $\begin{array}{l}\text { Polymorphic } \\
\text { bands }\end{array}$ \\
\hline E32-M36 & 83 & 14 \\
E33-M40 & 50 & 12 \\
E37-M38 & 43 & 13 \\
E34-M36 & 45 & 12 \\
Total & 231 & 51 \\
\hline
\end{tabular}

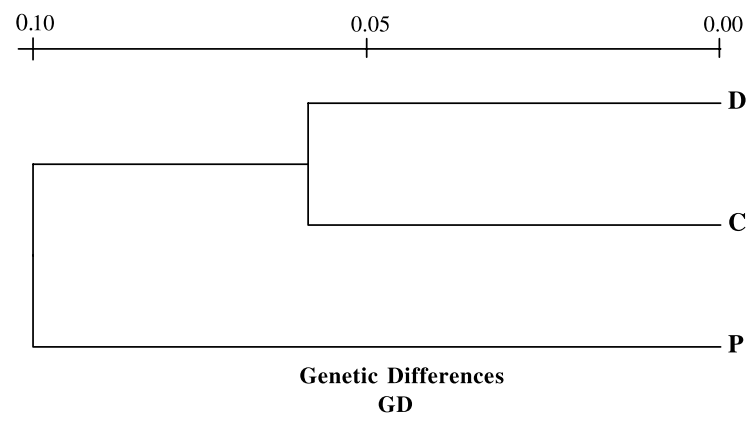

Fig. 3. Dendrogram, computed with SM index, defining genetic differences due to DNA sequence changes, between control (C) and $(\mathrm{D})$ dihydrophenanthrene or $(\mathrm{P})$ potassium dichromatetreated plants.

that at the concentration of pollutants used in our work, a greater genotoxic effect was observed for the inorganic substance (potassium dichromate) than for dihydrophenanthrene organic contaminant. In addition, a different polymorphic profile was obtained from different substances as showed in Fig. 2 and suggested from the dendrogram; these considerations indicated that DNA damage is different for each substance.

\section{Discussion}

The basic aim of biomonitoring is to supply data for an effective practical ecological control system. In particular, biomonitoring should act as an early warning system providing information about the seriousness of the pollution by sensitive assays. It is important especially for existing or potential contaminant-related genotoxic problem assessment, since most polluting substances have shown genotoxic effect (Casarett et al., 1995). In this regard, since the measurement of bioindicator response at lower biological organisation levels seems to be more sensitive to stressor effects than measurement at higher level, the best way to determine the concentration of a genotoxic substance should be by direct quantification of the genotoxic effect, i.e. DNA damage. 
In this work, genotoxic effect of inorganic (potassium dihicromate) and organic (dihydrophenanthrene) substances were investigated with the main model plant being Arabidopsis thaliana (L.) Heynh.

Several papers described the genotoxic effect of heavy metals and several organic substances in plants, based on comet assay or in micronucleus assays (Shaw et al., 1995; Camatini et al., 1998; Steinkellner et al., 1998). These approaches did not clarify the molecular mechanisms that induced DNA damage and are there as specific DNA target sequences. In this work AFLP approach was applied to evaluate genotoxic effect of potassium dichromate and dihydrophenanthrene on Arabidopsis thaliana (L.) Heynh. plants. In the case of chromium, it exists in the environment as two states, $\mathrm{Cr}^{3+}$ and $\mathrm{Cr}^{6+}$. This element and its salts have found a wide range of application in the chemical industry, artistic paints, anticorrosive paints, electroplating and stainess steel welding (Nieboer and Show, 1988). Hexavalent chromium $\left(\mathrm{Cr}^{6+}\right)$, which exists as an oxyanion at physiological $\mathrm{pH}$, is the most potent toxic compared with the trivalent form of chromium $\left(\mathrm{Cr}^{3+}\right)$. The main toxic effects induced by $\mathrm{Cr}^{6+}$ in humans are lung cancer, neurological alteration, skin burns, and dypnea. Chromium genotoxicity is manifest as gene mutations and DNA lesions (Singh et al., 1998). On the other hand the mechanism of dihydrophenanthrene-induced DNA damage is still unknown because very few studies have been conducted on this organic substance. An anti-algal activity was described for dihydrophenanthrere (Dellagreca et al., 2000) but the effect on other plants was unknown.

In our work the seed germination tests showed a toxic effect for both substances considered but did not clarify the target (biological membrane, protein, DNA) of two different substances. Using AFLP analysis, more polymorphic bands were detected with both substances treated. This suggests that dihydrophenanthrene as well as potassium dichromate has a genotoxic effect and that both substances induced DNA mutation. AFLP profile has shown that the sequence target of the two pollutant agents considered was different. This suggests that the genotoxic effects are directed to different target genes.

We conclude that AFLP is a powerful molecular marker for screening DNA damage induced by nonlethal levels of organic and inorganic contaminants.

Comparing AFLP approach with classic assay i.e. comet micronucleus test, several important differences can be underlined: (i) AFLP is a universal animal, plant and bacterial methodology. In the case of comet assays, a different approach can be developed for nuclei extraction from different types of organisms, (ii) AFLP approach offered the possibility of screening DNA damage in specific sequences. On the contrary comet assay or micronucleus analyse total nuclear DNA and not single sequences, (iii) AFLP as well as RFLP or RAPD are more sensitive than classic genotoxic tests because molecular tools could evidence a single DNA mutation.

AFLP allows simultaneous analysis of a large number of loci in a single assay and provides stable and reproducible patterns of band amplification compared to other molecular tools such as RAPD or RFLP. On this basis, AFLP is a new powerful tool for assessing DNA sequence alteration induced by environmental pollutants.

We underline that our work is a preliminary experiment conducted on a pool of Arabidopsis thaliana (L.) Heynh. plants and we cannot clarify the mechanisms of DNA damage. On the basis of AFLP analysis two possible mechanisms are hypothesized: DNA random breaking or mutation in the target sequences of AFLP enzymes (MseI and EcoRI). To verify this hypothesis AFLP methodology could be applied to single plants in many repetitions and in specific plants tissue to evaluate the effect of genotoxic substances on different plant organs.

A further consideration is that changes in the DNA fingerprints may be used to identify target genes for particular genotoxic agents. For example, it is worth investigating which particular DNA bands always appear or disappear when an Arabidopsis thaliana (L.) Heynh. plant is exposed to a particular agent. Characterisation of these DNA molecules using DNA sequencing techniques may enable the identification of specific sequences that are hotspots for mutation by particular agents; this will open up possibilities of designing specific assays for detection of specific agents.

Finally, further application of the DNA fingerprinting procedures discussed here may help explain the presence in the genome of preferential mutation points.

\section{References}

Camatini, M., Bonfante, P., Colombo, A., Urani, C., 1998. Molecular approaches to evaluate pollutants. Chemosphere 37, 2717-2738.

Casarett, L.J., Amdur, M.O., Klaassen, C.D., Doull, J., 1995. In: Klaassen, C.D. (Ed.), Casarett and Doull's Toxicology: the Basic Science of Poisons. McGraw Hill Companies, USA, pp. 199-267.

Citterio, S., Aina, R., Labra, M., Ghiani, A., Fumagalli, P., Sgorbati, S., Santagostino, A., 2002. Soil genotoxicity: a new strategy based on biomolecular tools and plants bioindicators. Environ. Sci. Tech. 36, 2748-2753.

Constantin, M.J., Nilan, R.A., 1982. Chromosomal aberration assays in barley (Hordeum vulgare) a report of the US environmental protection agency gene tox program. Mutat. Res. 99, 13-36.

Conte, C., Mutti, I., Puglisi, P., Ferrarini, A., Regina, G.R.G., Maestri, E., Marmiroli, N., 1998. DNA fingerprint analysis by PCR based method for monitoring the genotoxic effects of heavy metals pollution. Chemosphere 37, 27392749 . 
De Flora, S., Bagnasco, M., Serra, D., Zanacchi, P., 1990. Genotoxicity of chromium compounds. Mutat. Res. 238, 99-172.

Dellagreca, M., Fiorentino, A., Monaco, P., Pollio, A., Previtera, L., Zarrelli, A., 2000. Dihydrophenanthrene and phenanthrene mimics of natural compounds synthesis and antialgal activity. J. Chem. Ecol. 26, 587-595.

Fiskesjo, G., 1997. Allium test for screening chemicals; evaluation of cytological parameters. In: Wang, W., Gorsuch, J.W., Hughes, J.S. (Eds.), Plants for Environmental Studies. Lewis Publishers, New York, pp. 307-333.

Flury, B., 1988. Common Principal Components and Related Multivariate Models. Wiley, New York, pp. 258-259.

Fomin, A., Paschke, A., Arndt, U., 1999. Assessment of the genotoxicity of mine-dump material using the tradescantiastamen hair (trad-shm) and the tradescantia-micronucleus (trad-shm) bioassay. Mutat. Res. 426, 173-181.

Grant, W.F., 1994. The present status of higher plant bioassay for the detection of environmental mutagens. Mutat. Res. $310,175-185$.

Karp, A., Isaac, P., Ingram, D., 1998. Molecular Tools for Screening Biodiversity, first ed. Chapman \& Hall, London.

Knasmuller, S., Gottmann, E., Steinkellner, H., Fomin, A., Pickl, C., Paschke, A., God, R., Kundi, M., 1998. Detection of genotoxic effects of heavy metal contaminated soils with plant bioassays. Mutat. Res. 420, 37-48.

Koppen, G., Verschaeve, L., 1996. The alkaline comet test on plant cells: a new genotoxicity test for DNA strand breaks in Vicia faba root cells. Mutat. Res. 360, 193-200.

Lowry, L.K., 1995. Role of biomarkers of exposure in the assessment of health risks. Toxicol. Lett. 77, 31-38.

Marcon, F., Zijno, A., Crebelli, R., Carere, A., Veidebaum, T., Peltonen, K., Parks, R., Schuler, M., Eastmond, D.A., 1999. Chromosome damage and aneuploidy detected by multicolour FISH in benzene exposed shale oil workers. Mutat. Res. 445, 155-166.

Minissi, S., Lombi, E., 1997. Heavy metal content and mutagenic activity; evaluated by Vicia faba micronucleus test, of Tiber river sediments. Mutat. Res. 393, 17-21.
Mullis, K.B., Faloona, F.A., 1987. Specific synthesis of DNA in vitro via a polymerase-catalyzed chain reaction. Method. Enzymol. 155, 335-350.

Nieboer, E., Show, S.L., 1988. Mutagenic and other genotoxic effects of chromium compounds. In: Niragu, J.O., Nieboer, E. (Eds.), Chromium in the Natural and Human Environment. John Wiley and Sons, New York, pp. 399-441.

Savva, D., 2000. The use of Arbitrarily primed PCR (AP-PCR) fingerprinting detects exposure to genotoxic chemicals. Ecotoxicology 9, 341-353.

Shaw, G., Connell, D., Barron, W., 1995. The use of in vitro adduct formation to estimate the genotoxicity of residues at contaminated sites. Chemosphere 30, 957-1968.

Singh, J., Carlisle, D.L., Pritchard, D.E., Patieno, S.R., 1998. Chromium-induced genotoxicity and apoptosis: relationship to chromium carciogenesis. Oncol. Rep. 5, 13071318.

Sokal, R.R., Michener, C.D., 1958. A statistical method for evaluating systematic relationships. University of Kansas Scientific Bulletin 38, 1409-1438.

Steinkellner, H., Mun-Sik, K., Helma, C., Ecker, S., Ma, T.H., Kundi, M., Knasmuller, S., 1998. Genotoxic effects of heavy metals: comparative investigation with plant bioassays. Environ. Mol. Mutag. 31, 183-191.

Susa, N., Ueno, S., Furukawa, Y., Ueda, J., Sugiyama, M., 1997. Potent protective effect of melatonin on chromium(IV)-induced DNA single-strand breacks, cytotoxicity and lipid peroxidation in primary culture of rat hepatocytes. Toxicol. Appl. Pharmacol. 144, 377-384.

Tardiff, R.G., Lohman, P.H.M., Wogan, G.N., 1994. Methods to Assess DNA Damage and Repair. John Wiley \& Sons, New York.

Vos, P., Hogers, R., Bleeker, M., Reijans, M., Van de Lee, T., Horenes, M., Fiujters, A., Pot, J., Pelerman, J., Kuiper, M., Zabeau, M., 1995. AFLP: a new technique for DNA fingerprinting. Nucl. Acids Res. 23, 4407-4414.

Wang, W., Freemark, K., 1995. The use of plants for environmental monitoring and assessment. Ecotoxicol. Environ. Saf. 30, 289-301. 